\title{
THE PHILOSOPHICAL UNDERSTANDING OF COMPASSION AS A METHODOLOGICAL FOUNDATION FOR ITS FORMATION IN PRIMARY SCHOOL CHILDREN
}

\author{
Tatiana Solovyova \\ Pskov State University, Russian Federation \\ Victoria Guseva \\ Pskov State University, Russian Federation
}

\begin{abstract}
The relevance of the article is determined by the need for a philosophical aspect in the study of the category "compassion" for the discovery and understanding of new pedagogical possibilities of educational activity in primary school.

The purpose of the article is to convey to the pedagogical community the quintessence of the philosophical positions reflecting the ideas of compassion in world culture.

The methodology of the present study was the civilizational and axiological approaches; the historical and genetic method (theoretical), the study of the experience of educational organizations and personal pedagogical experience in school (empirical) were used in the work.

The authors concluded that compassion in the process of education should be perceived as a priority of moral health of the pupils.

The compassion is "stored" in the "collective unconscious" of humanity, reflecting the thoughts and feelings common to all people, resulting from their common emotional past. For formation at pupils of compassion it is essential to cause them emotional response created by the teacher, the pedagogical situation, that there is some "moral habit" ("emotional skill"), a member of the "Super-Ego" personality, in other words, conscience. The authors show the ways and methodical means that provide awakening, raising from the depths of the subconscious some innate need to do goodness, the desire to help.
\end{abstract}

Keywords: compassion; philosophical position; pupil; pedagogical ways and means.

\section{Introduction}

In the history of philosophy, the category "compassion”, in spite of cultural pluralism, was understood extremely closely, namely, as one of the greatest universal values (Zen'kovskij, 2001; Daniljuk, Kondakov, \& Tishkov, 2011; Solovyova \& Guseva, 2014), as a "central cultural value" (J. Heyzingi, 1992); as a virtue bestowed from above, which helps to overcome sinfulness, etc.

Studying the ideas of Confucius, who believed that "if one is striving for compassion, there will be no evil" and "only a compassionate person can both 
love people and hate them" (Semenenko, 1998, 266), suggests the correction of the goal of moral education of students: development in modern schoolchildren of "spiritual principles" of compassion, since with their help it is possible to maintain peace and smooth social contradictions in our difficult "unkind time". This educational goal is consistent with the statement of the French writer Francois Rene de Chateaubriand: “... The source of evil is vanity, and the source of good is compassion” (Ermishin, 2006, 1350).

The words of professor I.F. Kharlamov, who claims that every "comprehensively developed person must develop in himself $<\ldots>$ compassion" also sound significant in this contest (Kharlamov, 2004, 37).

Thus, the relevance of the study is determined by the urgent need of our pragmatically inclined society, which is divided and torn apart by contradictions, in considering compassion as a social medicine, a drug that should saturate children's souls with ideals of morality and ideas of good within the walls of a modern school.

The purpose of the article is to convey to the pedagogical community the quintessence of the philosophical positions reflecting the ideas of compassion in the world culture.

The article presents materials obtained using the following research methods: theoretical (historical-genetic method), empirical (study of the experience of educational organizations and personal pedagogical experience in school).

\section{The Results of Theoretical Research}

The study of foreign philosophical works (Kramer, 1977; Kuzishhin, 2003; Titarenko, 2002; Vasil'eva, 2001; Chzhuan-czy, 2005; Semenenko, 1987) using civilizational and axiological approaches, and the subsequent comparison of their materials with modern philosophical and pedagogical scientific sources allowed us to formulate the following positions.

First, compassion has been traditionally interpreted as the high moral quality of a perfect person (ideal, supernatural gift, humanity, supreme wisdom, "oil" in the lamp of the soul, etc.) and was considered to be the goal of education. In modern pedagogy, the upbringing of qualities in children (Shhurkova, 2010) has been replaced by the upbringing of value orientations, values, one of which is compassion (Daniljuk, Kondakov, \& Tishkov, 2011).

Secondly, when defining the concept of "compassion", the key term was "readiness" (willingness to help financially, verbally, spiritually). Most vocabulary and encyclopedic articles (Shapovalova, 2009; Ozhegov, 1986; Dal', 1935; Stepin, 2010; Davydov, 1993; Efremova, 2006; Slovar' russkogo jazyka,1983; Slovar' po jetike, 1989) also define compassion as willingness 
(willingness to help someone, come to the rescue, forgive someone, show indulgence, do good to everyone, give alms, give good advice, to an open dialogue with those in need of help etc.), revealing the activity-oriented character of nurturing compassion in schoolchildren.

Thirdly, since the times of ancient Egyptians and Indians (for example, "The Teaching of Ptakhotep (Kuzishhin, 2003)," the hymns of the "Rigveda” (1972), compassion has also been understood pragmatically, namely, as financial support (alms, welfare) or as activities aimed to provide this help (charity, philanthropy, care, patronage), targeting the pedagogical community to organize volunteer activities.

Fourth, the position in which compassion was seen as feeling (compassion, regret, pity, sympathy, duty, condescension, the combination of suffering and different types of love, etc.) does not lose its relevance; basically it implied the ability to rejoice together from the heart at an act of help, empathy for the afflicted, directing teachers to implement the emotiogenic function of the content of education.

The modern scientific community has advanced in revealing the essential elements, details and signs of the "compassion" category, revealing "exits" not only in the field of educational organization (pedagogy), but also in the field of valeology.

For example, the position of the American psychologist K. Nelson and her colleagues, who experimentally proved that showing compassion, doing good deeds, acts of altruism, leads to an improvement of mood and well-being, which gives the student positive emotions and benefits his mental health, is of interest (Nelson, Layous, Cole, \& Lyubomirsky, 2016).

P.A. Sorokin in the context of evolutionary psychology (the theory of creative altruism) described the ideal typology of altruism based on large-scale interviews and questionnaire studies (Sorokin, 1954), which allows to expand the methodological tools of nurturing compassion in extracurricular activities.

S. Sprecher and B. Fehr developed a scale of compassionate love, which allows to identify the stages of relations with close people, among which the key place is "compassionate love" (Sprecher \& Fehr, 2005), which gives educators the right to consider it as a principle of family education.

Scientist K. Nef performed a study aimed at disclosing the content of the scale of compassion for oneself (selt-compassion), through which it was experimentally proved that self-compassion significantly correlates with the positive results of a person's mental health (reducing depression and anxiety, life satisfaction) (Nef, 2003). She developed a scale of self-compassion, which includes the following items: kindness to oneself and others, social desirability, self-criticism, social closeness, emotional intelligence, perfectionism, anxiety, depression, satisfaction with life. For practicing educators, the materials of this 
study make it possible to diagnose the degree of self-acceptance (autosympathy), friendliness or hostility to one's own "I" when students are forming a positive selfconcept.

To solve the problem of effective socialization of schoolchildren, teachers can be advised to refer to the results of a study made by C. Oveis, E. Horberg, and D. Keltner, who experimentally studied the influence of pride and compassion as social functions in the process of identifying a person in the society (Oveis, Horberg, \& Keltner, 2010).

Using the historical genetic method (Koval'chenko, 2003) in the analysis of Russian philosophical thought in the study of the compassionate behavior of the Russian people allowed us to discover the following.

- The ideas of good-naturedness have always been characteristic of the Russian mentality; they have passed "a deep understanding of the moral meaning of life as responsibility to ancestors and descendants" (Novickaja, 2018, 5).

- Compassionate behavior has always been a "necessary condition for personal moral health" of a Russian person (Kljuchevskij, 1990, 78). In the work "Good People of Ancient Russia", the pre-revolutionary philosopher V.O. Klyuchevsky says that "pity for the poor and wretched is the feeling with which a Russian woman was born into the world" (Kljuchevskij, 1990, 81).

- Alms given "from hand to hand", moreover, secretly, so that no one would know about the act of help, was a Russian tradition. A pedagogical understanding of this phenomenon will help the educator to teach children the reflection of their own actions, since true compassion is selfless, does not require a "reward" even as praise, recognition of a good deed.

Thus, the compassion is "stored" in the "collective unconscious" of the Russian people, reflecting thoughts and feelings and arising from their common emotional past.

\section{The Research Methodology}

The methodology of the present study was the civilizational and axiological approaches. In the work, the historical and genetic method (theoretical) was used, the study of the experience of educational organizations (MBOU "Pskov Pedagogical Complex Education Center", MAOU "Lyceum of Economics and Fundamentals of Entrepreneurship No. 10") and personal pedagogical school experience (empirical). 


\section{The Interpretation of the Results of the Study}

The implemented philosophical and pedagogical analysis of literary sources made it possible to consider compassion as a personal readiness to selflessly do good, help those in need, fulfill one's human duty, not being afraid to make demands and, at the same time, show indulgence and tolerance.

Compassion should be understood as the basis for the formation of a student's moral and ethical orientation. Namely, from the sensual level of compassion, its simplest manifestations (pity, empathy, sympathy) to good thoughts and deeds. Then it is rising to a new level - "compassion”, sincere joy one feels after an act of help, to the level of forgiveness and help to an unpleasant person, ill-wisher or enemy.

Now we illustrate what has been said with the examples of educational activities of elementary schoolchildren.

So, at the lesson of Natural Environment in the first grade studying the topic "You and Your Friends" (the author of the school textbook is A.A. Vakhrushev and others), the teacher can offer a learning situation that causes pupils to show compassion of a sensual level, inviting them to perform the following tasks.

The worksheet depicts a picture of a crying child who has broken his knee. After examining the image, the teacher asks schoolchildren to answer a number of questions: what feelings did they have towards the child after studying the picture; what color would they choose to express their feelings towards the crying personage, etc.

After listening to the ideas of children and discussing them, the teacher offers pupils to express their sympathy for the crying child using speech clichés ("Don't cry, let's treat the wound with iodine and bandage", "You are a boy - men don't cry!", "It's not worth grieving!", "You'll get over it”, etc.), choosing the most suitable for this situation.

For example, during a Reading lesson in the second grade when working on a story "Blizzard" by V.A. Sukhomlinsky, teacher can offer pupils to imagine themselves to be the main characters who were alone during the blizzard on the way to school, and, using the mood lexicon, try to convey the feelings of the children.

After discussing this task with the pupils, the teacher invites them to think what they would do if they were the story's characters, how they would behave during a heavy snowstorm. In case of difficulty, ready-made answer variants are given for discussion using the "Good-Bad" method ("I will call for the adults"; "I will return home"; "I will wait until the end of the blizzard in the shelter (under the tree)"; "I will offer to go to school together"; "I will be brave and courageous and I will run quickly;" "I will be still feeling scared"), which involves highlighting the strengths and weaknesses of each decision. 
Solovyova \& Guseva, 2020. The Philosophical Understanding of Compassion as a Methodological Foundation for its Formation in Primary School Children

The next important conclusion of the study is the idea that for formation of compassion in a child it is essential to evoke in him an emotional response to a particular situation in order to subsequently form a "moral habit", the so-called "emotional skill", expressed in the fact that if this is not done, if you don't provide help, you will feel a certain "moral awkwardness".

Here is a fragment of a Natural Environment lesson in the fourth school grade on the topic "The 19th Century History Pages" (the authors of the textbook are A.A. Pleshakov and others).

The teacher suggests that primary school children read the text and mark it up at the end of each sentence (INSERT method).

In the spring of 1831, walking with his tutor Merder along the embankment of the Fontanka River, the future Emperor Alexander II noticed that an old man was lying on one of the barges under a dirty matting and was groaning. The Tsarevich ran across the shaky boards to the old man's barge.

Merder, seized by fear that the throne heir will fall into the water, rushed after him and saw how Alexander was carefully wiping the face of the unfortunate with a handkerchief. The teacher gave the Tsarevich a gold coin, which he put into the old man's hand.

After discussing the work with the text, the elementary school teacher gives the following task - "Using the "thick" and "thin" questions, formulate the question(s) to which you would like to find answer(s) after reading this text". Some examples of the children's questions are: "Why did Alexander II approach the old man?" ("Thick" question), "Could the teacher Merder be punished for "overlooking” the future emperor?" ("Thin" question), etc.

After listening to the questions formulated by the pupils, the teacher immediately answers the "thin" questions, writes problem questions on the board for further discussion during the lesson: "Think about why Alexander II himself did not disdain to approach the beggar?", "Why did he wipe the face of the beggar?", "Is it possible to say that the future emperor showed compassion in helping the old man?”, "Explain why he helped him?”, “Could he just walk past, because he is the sovereign?", "Do you think the future emperor told about his gesture to brothers and sisters? Why?" and other questions.

Then the teacher asks the younger schoolchildren to put themselves in the place of Alexander II and think about why he expressed compassion, not being afraid, for example, to get a serious illness from a homeless person and get sick; why the future sovereign could not have acted any other way?

After listening to the ideas of the children, the teacher asks to read the proverbs and answer again: “Don't judge a watermelon by the peel (Don't judge a book by its cover), don't judge a the person by the dress", "Do your duty without thinking about the outcome", "Who helped soon, he helped twice", "To save a friend is to save yourself", "If we don't help others, we'll get lost ourselves”, etc. 
As a result, younger schoolchildren come to the conclusion that Alexander II could not have acted differently; he fulfilled his moral, human duty without any hesitation.

Thus, the most important task of the teacher is to ensure that the student is developing an emotional skill that encourages him to show compassionate behavior. At the same time, it is important that the student would want to help not because of rational thinking, but because he cannot do otherwise, because he will "feel bad" from inaction. In modern psychological and pedagogical science, such an emotional skill is included in the structure of the "Super-Ego" of an individual, speaking in ordinary language, of conscience.

A growing person must set a high bar in his development, reaching a certain "ideal". The teacher's task is to help the child realize that ideal behavior is compassionate behavior, and "compassion is the feeling of strong people who can come to the rescue", "mercy is not a weakness, but a strength" (Solovejchik, 2017, 183).

We will illustrate the above-stated ideas with an example of a classroom hours in elementary school (1-2 grades).

The teacher begins the classroom hour by showing pupils a few photos of their peers. Photos offered for boys and girls differ. For girls, a handsome athletically built young man is depicted, in the other picture there is an "ordinary", common, unremarkable pupil, and for boys, on the contrary, their girl peers are shown, having the same characteristics.

After that the teacher asks the pupils to give a descriptive characteristic (both external and internal) to their peers in the photo, to express who they would like to be friends with and why, which of these children in the photo is in their opinion beautiful, strong, attractive, etc. As a rule, younger schoolchildren prefer peers from the first photos.

Later on the teacher says that he witnessed two situations during the school break. 1. "I watched during the break the boy and the girl shown in the first photo "nibbling" sunflower seeds, and when the bell rang, they quickly tossed them into the nearest flower pot. "At the door of their classroom, I asked them to clean up after themselves, but the children began to shake their heads and say that this was not their litter". 2. "At the next break in the school corridor, I noticed that the flower pot is clean and the children shown in the second photo are watering the flowers from a glass, each time again and again going to the toilet for water. I asked them: "Are you on duty today?" The response was: "No, the soil in the flower pot is very dry ...”.

After an emotional pause, the teacher again asked the younger schoolchildren to describe their peers in the photos and say with whom they would like to be friends and why, which of these children in the photos actually turned out to be beautiful and strong in their opinion and why? 
Solovyova \& Guseva, 2020. The Philosophical Understanding of Compassion as a Methodological Foundation for its Formation in Primary School Children

At the end of the discussion, younger schoolchildren come to the conclusion that physical appearance doesn't make a person strong and beautiful, but personal qualities like the willingness to "help plants" in this case.

\section{Conclusions}

Summarizing the main results of the study, we came to the following conclusions.

- The formation of compassion as a universal value in contemporary schoolchildren can contribute to the consolidation of the world community in the future.

- Compassion as the ideal of a perfect person must be considered as one of the goals of education in a contemporary school.

- $\quad$ The emotiogenic function of education is realized through cultivating compassion in educational activities.

- It was revealed that manifestation of compassion by pupils helps to improve their mental and moral health.

- When interpreting the concept of "compassion", the key term is "readiness" (willingness to help financially, verbally, spiritually).

- The basis of volunteer activity is not only pragmatic understanding of compassion, but also compassionate activities (such as charity, philanthropy, care, patronage)

- For formation of compassion in pupils it is essential to evoke emotional response, which will develop a moral habit that is part of "Super-Self" or "Super-Ego" structure of a personality.

- The scale of self-compassion can act as an additional tool for diagnosing a positive self-concept formation degree in schoolchildren.

\section{References}

Neff, K. (2003). The Development and Validation of a Scale to Measure Self-Compassion. Self and Identity, 2, 223-250.

Nelson, S.K., Layous, K., Cole, S.W., \& Lyubomirsky, S. (2016). Do Unto Others or Treat Yourself? The Effects of Prosocial and Self-Focused Behavior on Psychological Flourishing. Emotion, 1-12.

Oveis, C., Horberg, E.J., \& Keltner, D. (2010). Compassion, Pride, and Social Intuitions of Self-Other Similarity. Journal of Personality and Social Psychology, 4, 618-630.

Sprecher, S., \& Fehr, B. (2005). Compassionate love for close others and humanity. Journal of Social and Personal Relationships, 22, 629-652.

Chzhuan-czy. Put' polnoty svojstv. (2005). (L. Pozdneeva. Trans.). Moskva: Jeksmo.

Dal', V.I. (1935). Tolkovyj slovar' zhivogo velikorusskogo jazyka (t.2). (A. I. Bodujena-deKurtene. Ed.). Sankt-Peterburg: Tovarishhestvo M. O. Vol'fa. 
Proceedings of the International Scientific Conference. Volume III, May $22^{\text {th }}-23^{\text {th }}$, 2020. 587-595

Daniljuk, A.Ja., Kondakov, A.M., \& Tishkov ,V.A. (2011). Koncepcija duhovnonravstvennogo razvitija $i$ vospitanija lichnosti grazhdanina Rossii. Moskva: Prosveshhenie.

Davydov, V.V. (1993). Rossijskaja pedagogicheskaja jenciklopedija (t.2). Moskva: Bol'shaja rossijskaja jenciklopedija.

Efremova, T.F. (2006). Sovremennyj tolkovyj slovar' russkogo jazyka (t.2). Moskva: AST.

Ermishin, O.T. (2006). Aforizmy. Zolotoj fond mudrosti. Moskva: Prosveshhenie.

Harlamov, I.F. (2004). Pedagogika. Minsk: Vysshaja shkola.

Heyzingi, J. (1992). Homo ludens. $V$ teni zavtrashnego dnja (V.V. Oshis, Trans.). Moskva: Progress.

Kljuchevskij, V.O. (1990). Istoricheskie portrety. Dejateli istoricheskoj mysli. Moskva: Pravda. Koval'chenko, I.D. (2003). Metody istoricheskogo issledovanija. Moskva: Nauka.

Kramer, S.N. (Ed.). (1977). Mifologija drevnego mira (V.A. Jakobson. Trans.). Moskva: Vostochnaja literatura RAN.

Kuzishhin, V.I. (Ed.). (2003). Istorija Drevnego Vostoka: Teksty i dokumenty. Moskva: Vysshaja shkola.

Novickaja, M.Ju. (2018). Duhovno-nravstvennoe vospitanie na osnove tradicionnoj otechestvennoj kul'tury. Nachal'naja shkola, 8, 3-8.

Ozhegov, S.I. (Ed.). (1986). Slovar' russkogo jazyka. Moskva: ID Oniks.

Rigveda. Izbrannye gimny. (1972). (T. Ja. Elizarenkova. Trans.). Moskva: Glavnaja redakcija vostochnoj literatury izdatel'stva "Nauka”.

Semenenko, I.I. (1987). Aforizmy Konfucija. Moskva: Izdatel'stvo Moskovskogo universiteta.

Shapovalova, O.A. (Ed.). (2009). Jetimologicheskij slovar' russkogo jazyka. Rostov-na-Donu: Feniks.

Shhurkova, N.E. (2010). Programma vospitanija shkol'nika. Moskva: Centr «Shhurkova N.E. Pedagogicheskij poisk».

Slovar' po jetike. (1989). Moskva: Politizdat.

Slovar' russkogo jazyka (t.2). (1983). Moskva: Russkij jazyk.

Solovejchik, S. (2017). Nepropisnye istiny vospitanija. Moskva: Izdatel'stvo AST.

Solovyova, T.A., \& Guseva, V.A. (2014). Teoreticheskaja model' kategorii «miloserdie shkol'nika» kak sociokul'turnoj dominanty v processe duhovno-nravstvennogo razvitija sovremennyh shkol'nikov. Vestnik Pskovskogo gosudarstvennogo universiteta, 5, 342-349.

Stepin, V.S. (2010). Novaja filosofskaja jenciklopedija (t.1). Moskva: Mysl'.

Titarenko, I.N. (Ed.). (2002). Filosofija Lucija Anneja Seneki i ee svjaz's ucheniem Rannej Stoi. Rostov-na-Donu: SKNC VSh.

Vasil'eva, Z.I. (Ed.). (2001). Istorija obrazovanija i pedagogicheskoj mysli za rubezhom i v Rossii. Moskva: Izdatel'skij centr "Akademija”.

Zen'kovskij, V.V. (2001). Istorija russkoj filosofii (t.1). Moskva: Akademicheskij Proekt, Raritet. 